\title{
Theme-based Book Review: public policy problems, and solutions?
}

\author{
Christopher L. Atkinson ${ }^{1} \mathbb{D}$
}

Accepted: 14 February 2022 / Published online: 3 March 2022

(C) The Author(s), under exclusive licence to Springer Science+Business Media, LLC, part of Springer Nature 2022

\begin{abstract}
This theme-based book review considers three recent titles related to public policy problems, processes, and solutions, from scholarly and practitioner perspectives: The Political Formulation of Policy Solutions, edited by Philippe Zittoun, Frank Fischer, and Nikalaos Zahariadis; A Guidebook for City and County Managers: Meeting Today's Challenges, by James M. Bourey; and Solving Public Problems: A Practical Guide to Fix Our Government and Change Our World, by Beth Simone Noveck.
\end{abstract}

Keywords Public policy $\cdot$ Multiple streams theory $\cdot$ Local government $\cdot$ Public administration $\cdot$ Book reviews

\section{Introduction}

“A Garbage Can Model of Organizational Choice," published in 1972, has proven useful well beyond its original focus - foreshadowing the peculiar world of public policy in its current difficult context, with policy spheres looking more like 'organized anarchies' characterized by "problematic preferences, unclear technology, and fluid participation," and where organizations could be seen as "collections of choices looking for problems, issues and feelings looking for decision situations in which they might be aired, solutions looking for issues to which they might have an answer, and decision makers looking for work" (Cohen, March, \& Olsen, 1972, p. 1). Decision making, as Cohen, March, and Olsen (1972) observed, might not even

Christopher L. Atkinson

Catkinson1@uwf.edu

1 Department of Administration and Law, University of West Florida, 11000 University

Parkway, Bldg 70, 32514 Pensacola, Florida, USA 
be focused on solving problems. Inaction might seem like a winning strategy, when sharing victory with ideological enemies is repulsive; movement can seem like failure. People have shown themselves to be aggressive in political circles; appeasement does not work, and some refuse to see their own dark tendencies (Hennelly, 1988). It is a time when a riotous mob seeking to overturn an election has been deemed by a major political party to be nothing more than "ordinary citizens engaged in legitimate political discourse.” (Weisman \& Epstein, 2022).

It follows then that, while public values are still important, there is disagreement, maybe intractable, about the nature of those values, and the role of government to act according to them, and to protect them. The manner of decision-making and policy implementation in government remains incompletely understood, inviting simplistic explanations and appeals to change. It could seem like the policy garbage can is truly full of garbage. Multiple streams theory, similarly, depicts the varying chances that options amid an abyss of solutions have for becoming enacted public policy; it is worth wondering, in an age of political polarization, about the potential for publiccentered policies when so much is at stake from a political perspective, and so few people seemingly willing to compromise. Some officials may promise an outcome and then tell elaborate stories about why it has not happened. As the rhetoric-action gap grows, elected officials might be willing to ignore legitimate problem-solving altogether, while storytelling about what has occurred allows official actors to escape a 'narrative trap' (Grzywacz, 2021).

The difficult context of public policy is likely made worse and more fraught by the presence of the profane trinity of proto-authoritarianism, misinformation, and social media as a vector for the exchange of information and, seemingly in equal turns, nonsense. A connection between population and misinformation is revealed, questioning recognized facts and giving breathing room to substitute realities (Hameleers \& Minihold, 2020). The result is an irrational muddle that leads to the worst sort of antidemocratic tendencies (Schwartz, 1984). When shared goals become elusive, and various policy staff and the public become activated in ways that draw or limit attention, choices may not match any semblance of common sense.

This theme-based book review considers three recent titles related to public policy problems, processes, and solutions, from scholarly and practitioner perspectives: The Political Formulation of Policy Solutions, edited by Philippe Zittoun, Frank Fischer, and Nikalaos Zahariadis; A Guidebook for City and County Managers: Meeting Today's Challenges, by James M. Bourey; and Solving Public Problems: A Practical Guide to Fix Our Government and Change Our World, by Beth Simone Noveck.

Philippe Zittoun, Frank Fischer, and Nikolaos Zahariadis (Eds.). (2021). The Political Formulation of Policy Solutions: Arguments, Arenas, and Coalitions. Bristol, UK: Bristol University Press. 210 pp. ISBN: 978-1529210347 (hbk, \$139.95 USD), ISBN: 978-1529210361 (ePub, \$48.95 USD).

As policy studies have advanced, there has been more acceptance that policy solutions do not exist as neutral interventions in society; rather, policies are shaped by those that created them, their best intents, assumptions, and biases, and in turn policies shape what is considered to be possible in responding to public problems. Far from always evidencing a clear-headed, rational response to the output of a problem definition process, policy solutions exist as a response to the competition among vari- 
ous interested groups, in various arenas, in a manner that might not yield an optimal response. Alternatives, to the extent that they are sensibly evaluated, are limited by understanding and previously-made decisions. Conflict and coalition-building inform a process where one interested side in a policy debate might 'win', but the rest of us could very well lose. The literature focuses greatly on instrumental responses, but political wherewithal has greater influence on processes and outcomes than might be usually thought.

In their new book, Zittoun, Fischer, and Zahariadis have assembled an especially engaging look at the political side of policy solutions, with chapters that explore the topic in a range of contexts. The book is informed by multiple streams theory and study of policy under conditions of ambiguity (Kingdon, 1984; Zahariadis, 2003), as well as garbage can models (Cohen, March, \& Olsen, 1972). These perspectives have resonated strongly with me both in academic study and in viewpoints developed while working in the public sector. After an introduction by the editors, the book offers eight chapters taking up different aspects of the topic.

Chapter two begins with a consideration of German pension policy from the perspective of argumentative couplings, or how policy instruments become defined as solutions. I found points about 'upcycling' old policy solutions for new purposes, softening up the policy community so that they are more amenable to utilizing the solution in the proposed way, and the model of six coupling and non-coupling argument types, to be especially intriguing. Chapter three continues the discussion about binding problems and solutions with a review of U. S. agriculture policy, emphasizing the importance of context (economic, institutional, and political) in acting as a constraint on power and problem-solution argumentation; the reform-resistance of direct payments to farmers under the Farm Bill takes center stage here. Chapter four continues the look at binding arrangements, this time with framing through expert reporting. The distance between scientific controversy and public controversy can be significant, especially when science demands business deviate from its normal practices; there are seemingly no absolutes when money and power are involved. The chapter includes a number of examples, one being algae on beaches in Brittany that shows how a focusing event can trigger a series of responses that are almost like theater - commissioning a 'blue ribbon' panel, for instance - but the lack of alignment between scientific viewpoints and political agendas might scuttle otherwise reasonable policy changes.

Zahariadis explores value acceptability in chapter five, finding that four factors improve the viability of solution options: "side payments, institutional rule manipulation, short time horizons, and advocacy/framing" (2021, p. 93). The work of policy entrepreneurs is instrumental, and the activities of advocates can go a long way toward legitimizing would-be solutions. Underpinning the discussion are frameworks that tend toward or seek stability, but in today's unsettled environment, we have to think about the actions of those who are non-cooperative, and who may seek to mislead, that do not value stability. The chapter brought to mind policy by due date, and the sense of urgency - real or perceived - that may force the policy process forward. Further, policy packages have at least an appearance of being complete, and so the assumption may be that there is a level of quality in the solution, but this may prove illusory. 
Chapter six utilizes the French example of carbon capture and storage to illustrate the idea of policy ownership. The comment about industrialists favoring a solution if it benefitted them "either as a new business or as a public relations exercise" (Chailleux, 2021, p. 122) seemed perceptive and applicable broadly, beyond this particular case. In policy, ideas (good and bad) can persist indefinitely, as long as they are not exposed to public scrutiny. Policies have to be not only understandable to a lay audience - they should also be good ideas in the first place. Chapter seven considers the Dutch experience with immigration policy, suggesting that through targeting, "people are classified and grouped into policy-relevant categories... resembling who the government identifies is part of, or responsible for, the policy problem or solution, binding both together in a causal chain" (Van Breugel, 2021, p. 138). By choosing a different word for targeting (calling it quality instead, for example), real intents for policies that might be construed as an effort to marginalize groups can be masked.

A standout in the book is the chapter on Nevada (USA) college governance, by Martinez (2021). Discursive ideas were circulated in this case to encourage retention of centralized approaches, even though these failed to achieve optimal outcomes for students and workforce aims. It occurred to me that those in the policy sector do not actually have to want a solution to their policy problems, but they have to be seen as looking for one, for them to be seen as doing their jobs. Opinions might be requested but not wanted, and impartiality in views of public issues may not be desired, either, even if requested.

The book finishes up with a chapter on road space reallocation through lenses of problematization and interessement, noting unlikely alliances in disjointed contexts. Fuzziness in a solution might be desired, as the usefulness of a proposed solution can be extended to fit a potential variety of problems. Road safety, for example, might shift at some point to achieve improved social justice. The solutions in public policy often have a life of their own, beyond the original problem, no matter how clearly defined.

All the chapters provided interesting perspective on their specific topic areas, leading to an enriching whole. As a minor point, I would have enjoyed reading more about the methods and analyses in some chapters, as this work is often data-driven and not merely conceptual, but this material may have been left out due to space considerations. This noted, the book provided an enjoyable read, and the specific examples were given in enough detail to make plain the interplay of intents and outcomes, and how theory, especially multiple streams theory, can be brought to bear on improving understanding. I am pleased to recommend the book for public policy scholars, as well as libraries, and potentially public policy courses seeking to provide examples of theory application.

James M. Bourey. (2022).A Guidebook for City and County Managers: Meeting Today's Challenges. New York, NY: Routledge. 148 pp. ISBN: 978-1-03-219798-2 (hbk, \$59.95 USD), ISBN: 978-1-00-326275-6 (ebk, \$22.95 USD).

A Guidebook for City and County Managers: Meeting Today's Challenges brings James Bourey's extensive experiences in managing local government to a host of pressing societal challenges. The book is practitioner-oriented; at only 148 pages, it can be read in one or two sittings, and yet covers a remarkable breadth of topics by focusing on the major issues as they involve local government specifically. 
The book begins with a statement of values for local government leadership that, in simpler times, might be too obvious to mention. Engaging in a spirit of collaboration, taking responsibility for one's actions, and doing what is right are highlighted, as are the complementary (but very different) roles of council and manager. The first content section is on social justice - a particularly important topic recently given strife in cities over discriminatory practices and over-reach by police departments; Bourey makes a number of valuable recommendations to address policing issues without 'defunding the police'. I appreciate that the book starts with this because there are opportunities for local governments to understand social justice and work to make it a reality for more citizens. Bourey warns against gentrification without attention to social equity issues, and this is another wise point.

Local government finance is addressed next, with recommendations for longerterm forecasting and changing needs for fees and benefits. Included in this section is an admonition to pay due regard to rating agencies, and also a strategy for funding not-for-profit organizations.

Along the way, we are treated to real-life examples of success and moments when other approaches may have improved outcomes. Chapters are present on land-use and infrastructure, addressing sustainability and global climate change, and housing. A chapter on economic development is included. As a former economic development staff member, I must admit my concern about the benefit that economic development projects provide, and notably when the promised jobs and positive financial impact to a community fail to be realized, to the point where providing no incentives at all is a better idea (Reese, 2014). Bourey reminds practitioners of the importance of ensuring success from such ventures, including the provision of claw back mechanisms when benefits are not seen, and also the potential return from acting regionally on economic development initiatives.

Chapters on education and health initiatives follow. In the instance of the health care chapter, I felt the material was spot-on, and wish there might have been more of it. Points about indigent care and employee health were both useful and enlightening. The chapter on intergovernmental relations includes a case discussion that shows why simple answers do not always work in government. Chapters on information technology, public engagement, and a conclusion finish the book.

For the most part, the book provides quick, shrewd analyses into the most pressing facets of various challenges facing local government. As the book was written for a specific audience, it would be hard for me to quarrel with the material presented, which seems very appropriate for busy people that may benefit from a few important major points and some detail to support their importance. It is essential that local government be part of the solutions for many of these societal problems, and cities and counties have valuable roles to play. As a criticism, the book relies a bit much on Wikipedia; for an academic book, this would be unacceptable, but even the use in a practitioner text bothered me, as there are clearly more authoritative sources to consult.

The book is appropriate to its intended practitioner audience; I think it would be of interest not only to local government administrative leaders, but also to elected officials, who may not have a full grasp of the range of issues that face local governments, providing ordeals to overcome, but also opportunities if handled well. 
Beth Simone Noveck. (2021). Solving Public Problems: A Practical Guide to Fix Our Government and Change Our World.New Haven, CT: Yale University Press. 449 pp. ISBN: 978-0300230154 (hbk and ebk, \$30 USD).

In Solving Public Problems, Beth Simone Noveck asserts that "the tools to solve the deepest problems of our democracy are in our own hands...I have seen countless examples of activists, community leaders, public servants, and changemakers... working with their governments to solve real problems" (2021, p. ix). Noveck goes on to state that citizens need to be involved in the way society solves problems, but that Americans are unhappy and fed up with how government has handled things so far; it would be better if the "experience, know-how, and wisdom of ordinary people" (2021, p. xi) were utilized to solve problems in a participatory way, so that we could move beyond what are common inflamed opinions. Recommending that all public servants have innovation skills, and embrace new ways of working, Noveck suggests that even the most difficult problems can be broken down and solved. Her aim for the book, she writes, is "to equip individuals with a combination of qualitative and quantitative skills needed to become powerful change makers and, by working differently, to improve the effectiveness, equity, and legitimacy of our institutions" (p. 6).

Noveck begins the book highlighting the January 6, 2021 attacks and insurrection at the United States Capitol, and labeling Donald Trump as one of the worst U.S. presidents. This seemed an odd choice as her aim is to bring the public into public problem solving; this opening salvo might have offended a lot of her potential readership. She notes her experiences working with the Office of Innovation in the state of New Jersey, where she worked closely with others to provide information to the public about COVID-19, answering difficult questions by collaborating with a variety of other stakeholders and resources. She apparently did this quickly and efficiently, and suggests in a roundabout way that all government should be this simple and effective. She suggests a list of seven major skills for public problem solvers, among them problem definition, human-centered design, and data-analytical thinking; these skills generally guide the content of the books chapters. Of problem definition, Noveck writes that "public problem solvers know how to define a problem that is urgent, that matters to real people, and that can be resolved" (2021, p. 13). This is idealistic, but possibly simplistic and not realistic, given how much trouble problem definition is in practice.

The book brings to the reader a large array of examples of success in public service from around the world, and in the space available, provides a broad overview of a variety of aspects that could be improved to enhance public problem solving. Noveck's aim for the book is certainly laudable. I am not troubled at all by a moonshot argument that public problems have solutions, and we need to figure them out. Some of the resources included are very useful, such as the public problem-solving canvas, which could have benefit for public facilitation. I especially appreciated the 'to do' lists in each chapter, which offer a lot think about. It is easy to see how public organizations becoming more agile would be a good thing.

I agree with Noveck's position on involving the public in government, even though I know from my experience as a practitioner that apathy is real, resources for public participation in government are slim or none in many cases, and even given the opportunity and welcome, far fewer people show up for events than we might like. 
I offer that organizations and the people in them are complex, and simple answers to incredibly difficult questions are often wrong, so I am wary of anyone that says our inability to solve problems is because we have overlooked skill development. As much as crowdsourcing provides an opportunity for the public to get involved in decisions and potential solutions, and the case has been made for the wisdom of crowds (Surowiecki, 2004), the public can still make some bad decisions. For example, if one asks the public in an online poll to name a polar research ship, they might tell one to name it "Boaty McBoatface" and not the RRS Sir David Attenborough (Rogers, 2016). Often, the public is of the opinion that government should be somebody else's problem, cloaked in invisibility (Adams, 1982) until some favored politician says it should be a target for outrage. Still, the loudest voices are not always the more correct in their assertions and demands. And the simple fact of the matter is that society depends on careful, consistent function of government, informed by significant expertise in subject matter that is, sorry, just not the domain of the average person on the street.

It is true of course that many segments of the public are angry; anti-intellectualism has been a runaway train for a very long time (Hofstadter, 1963), and so the public elects people like the former U.S. president, who are supported because they are from the private sector, seen as an outsider to the Washington morass, and likeable relative to career public servants. The public wants to elect people who get the job done, but may not recognize that the job actually gets done by public administrators. They may believe a businessperson will run government better than public officials, and become expert in public service immediately on taking the job, even though businesspeople frequently and demonstrably fail at business - it is only a rare few that create companies that become amazingly successful. Noveck also does not trust business very much, as she questions the aim for some business interests to try to make money from solving societal problems (p. 42). I differ in some respects, because if business can solve our greatest societal challenges, then they have likely earned their money. Why turn down the help?

I found the tone of the book at times to be proud and condescending. As an example, early on in the text, Noveck writes that "for every person I meet who has made effective change, I meet ten with the desire but not the capacity to make a difference" (p. 7). I would find the notion that public problems exist because people lack skills to be laughable, if Noveck was not so earnest in the presentation. In my view, it is not lack of skill development that primarily prevents people from solving problems. Most people are actually not actively trying to thwart the public interest. They are simply bounded by their ability to understand, process, and comprehend (Simon, 1947); they do not agree with others on what constitutes the public interest, and nevertheless defend their view of it, leading to conflict. To the extent that government works at all, we are relying on competent public officials. The policy process is complex, difficult, prone to error, and heavily burdened by the proclivities of activists, lobbyists, and elected officials - some of whom demand approaches that have no basis in reality and are not supported by anything. While Zittoun, Fischer, and Zahariadis, and the authors in their collection might be concerned about the role of policy entrepreneurs and its impact on public outcomes, Noveck demands more policy entrepreneurship in government. Solving public problems requires being aware of more nuanced aspects, 
and throughout Noveck's book, I could see multiple streams theory and garbage can models at work in the examples provided.

I was frequently unclear on the intended audience for the book, but it is probably not well-seasoned, competent public administrators. While the book is full of examples of problems being solved, often there is less detail provided on the cases mentioned than would be helpful to provide for rich understanding. The book relies on some important concepts that should be of interest to public administration readers, but much literature on topics, for example public participation in policy circles, is not mentioned. There is perhaps too much emphasis on randomized control trials. I disagree strongly that government simply needs a new curriculum (an idea Noveck mentions frequently), when public administration schools do yeoman's work in helping to shape the future of public service. If everyone is innovating, who will do the actual work? Public administration has been talking about public policy and solving public problems for years, and schools of public administration have been teaching it; public administrators have been solving problems for the public long before this book was written. If anything, an introductory public administration course should be mandatory for all college graduates.

\section{Synthesis}

All three of the books in this themed review take up public problem solving, with very different results, for quite different likely audiences. It is important to come to terms with what led society to the place it finds itself in now, and while existing processes have not been wholly satisfactory, the notion that innovation and citizen involvement - as much as I favor it and support such efforts - will probably not lead to the desired results. There is simply too much in the primordial policy soup right now that favors division, blaming, and service of political ends.

The collection edited by Zittou, Fischer, and Zahariadis makes statements about various examples of policy formation with a distinctly political perspective, as well as asking questions about the space that may exist between rhetoric and practical aspects of policymaking. The Bourey text makes clear that, when confronted with so many potential issues in local government, it might be best to focus on a few important aspects, across a larger array of values - this would be more than enough to inform the work of an impressive career as a government leader. Noveck's book brings to light a vast array of examples, and calls for citizens to become involved in government as change-makers, with government personnel becoming free to innovate. It might be suggested, though, that in these difficult times, models of policymaking that do not require preconditions of rationality are most appropriate. Choices can and will be made, even if problems are not being resolved (Cohen, March, \& Olsen, 1972) - and that is a problem that continues to look for a solution.

\section{Declarations}

The author has no relevant financial or non-financial interests to disclose. 
The author certifies that he has no affiliations with or involvement in any organization or entity with any financial interest or non-financial interest in the subject matter or materials discussed in this manuscript.

The author has no financial or proprietary interests in any material discussed in this article.

Conflict of interest The author has no conflicts of interest to declare that are relevant to the content of this article.

Informed Consent This research does not involve human participants and/or animals.

Because the work does not involve human subjects, informed consent is not applicable.

\section{References}

Adams, D. (1982). Life, the universe and everything. Harmony Books

Chailleux, S. (2021). The marks of ownership: The promotion of carbon capture and storage in France. In P. Zittoun, F. Fischer, and N. Zahariadis (eds.), The political formation of policy solutions: Arguments, arenas, and coalitions (pp. 115-136). Bristol University Press

Cohen, M. D., March, J. G., \& Olsen, J. P. (1972). A garbage can model of organizational choice. Administrative Science Quarterly, 17(1), 1-25

Grzywacz, A. (2021). The Association of Southeast Asian Nations' narratives of non-compliance with norms: Shaming and escaping a narrative trap. Media, War \& Conflict, advanced online publication, 1-19. DOI https://doi.org/10.1177/17506352211053183

Hameleers, M., \& Minihold, S. (2020). Constructing discourses on (un)truthfulness: Attributions of reality, misinformation, and disinformation by politicians in a comparative social media setting. Communication Research. DOI https://doi.org/10.1177/0093650220982762

Hennelly, R. K. (1988). The psychological roots of political and ideological violence: A Jungian perspective. Alternatives: Global, Local, Political, 13(2), 219-252

Hofstadter, R. (1963). Anti-intellectualism in American Life . Knopf

Kingdon, J. W. (1984). Agendas, alternatives, and public policies. Brown: Little

Martinez, M. (2021). Discourse coalitions and the messiness of policy solutions: College governance in Nevada. In P. Zittoun, F. Fischer, \& N. Zahariadis (Eds.), The political formation of policy solutions: Arguments, arenas, and coalitions (pp. 151-172). Bristol University Press

Noveck, B. S. (2021). Solving public problems: A practical guide to fix our government and change our world. Yale University Press

Reese, L. A. (2014). The alchemy of local economic development. Economic Development Quarterly, 28(3), 206-219

Rogers, K. (2016, March 21). Boaty McBoatface: What you get when you let the internet decide. The New York Times.https:/www.nytimes.com/2016/03/22/world/europe/boaty-mcboatface-what-youget-when-you-let-the-internet-decide.html

Schwartz, D. (1984). Totalitarian tools: Preface to a theory. Alternatives, 10(2), 255-266

Simon, H. A. (1947). Administrative behavior; a study of decision-making processes in administrative organization. Macmillan

Surowiecki, J. (2004). The wisdom of crowds: Why the many are smarter than the few and how collective wisdom shapes business, economies, societies, and nations. Doubleday \& $\mathrm{Co}$

Van Breugel, I. (2021). Anticipating public approval in the binding of immigrant integration problems and solutions. In P. Zittoun, F. Fischer, \& N. Zahariadis (Eds.), The political formation of policy solutions: Arguments, arenas, and coalitions, pp. 137-150. Bristol University Press

Weisman, J., \& Epstein, R. J. (2022, February 4). G.O.P. declares Jan. 6 attack 'legitimate political discourse'. The New York Times.https://www.nytimes.com/2022/02/04/us/politics/republicans-jan6-cheney-censure.html

Zahariadis, N. (2003). Ambiguity and choice in public policy: Political decision making in modern democracies. Georgetown University Press 
Zahariadis, N. (2021). Coalitions and values in the flow of policy solutions. In P. Zittoun, F. Fischer, \& N. Zahariadis (Eds.), The political formation of policy solutions: Arguments, arenas, and coalitions (pp. 93-114). Bristol University Press

Publisher's Note Springer Nature remains neutral with regard to jurisdictional claims in published maps and institutional affiliations. 